\author{
ALEKSANDRA WALKIEWICZ \\ (D) https://orcid.org/0000-0002-6849-6132 \\ Uniwersytet Mikołaja Kopernika w Toruniu \\ Toruń
}

\title{
Glottodydaktyka a kompetencja komunikacyjna w dobie komunikacji elektronicznej
}

\author{
Teaching communication skills in the era of electronic communication
}

\begin{abstract}
As Internet applications and online communication become more and more popular, language teaching faces new challenges and needs. Using electronic forms of communication, our students are often able to deal with everyday problems in an efficient way, even though their language skills may not be up to the standards drawn in the CERF. Meanwhile, the lexical and grammar contents of teaching curricula and language textbooks do not always respond to the emerging needs of online communication. The purpose of this paper is to reflect on the impact of the growing interest in Internet solutions on PFL teaching practice, with reference to language level standards, teaching curricula, exam standards and textbook content, as well as student motivation level. All of these issues seem particularly important in times of pandemic, when online communication has become a necessity rather than an option.
\end{abstract}

Keywords: communication skills, electronic communication, Polish as a Foreign Language

\footnotetext{
* Niniejszy tekst przygotowano do druku przed wybuchem pandemii wirusa SARS-CoV-2, która rozpoczęła się w trakcie procesu wydawniczego. Artykuł zostanie więc opublikowany w momencie, gdy komunikacja elektroniczna stanie się już nie tyle wyborem, lecz koniecznościa. Poruszane tu kwestie wydają się tym istotniejsze, a przegląd zagadnień, które warto by uwzględnić w programach nauczania i scenariuszach lekcji, wymaga uzupełnienia m.in. o struktury i leksykę niezbędne do uczestnictwa w zajęciach uniwersyteckich prowadzonych online. Potrzeba też głębszej refleksji nad innymi dziedzinami życia, w których uczący się jpjo zmuszeni są do komunikowania się w sposób zdalny. Nie jesteśmy w stanie stwierdzić, w jakim stopniu dzisiejsze zagrożenie epidemiczne wpłynie na przyszłe zachowania komunikacyjne naszych studentów, a także jaki kształt będą miały po roku 2020 prowadzone przez nas zajęcia językowe. Można jednak zakładać, że porozumiewanie się i załatwianie spraw online stanie się na długo ważną częścią naszej rzeczywistości, której nie sposób ignorować w glottodydaktyce. Warto też pamiętać, że studenci wyrażali coraz większe zainteresowanie elektroniczną formą komunikacji już przed rozpoczęciem pandemii. Ten stan rzeczy będzie się więc prawdopodobnie utrzymywał również wtedy, gdy powrócimy do tradycyjnych form kontaktu.
} 
Przygotowanie do egzaminu certyfikatowego na poziomie B1

Zadanie: dialog z egzaminatorem

Egzaminatorka (wciela się w rolę turysty): Przepraszam, jak dojść z Collegium Maius do Galerii Plaza?

Student obcokrajowiec (uprzejmie, poprawną polszczyzna): Musi pani zainstalować sobie w telefonie aplikację Google Maps lub Jakdojade.

\section{Uwagi wstępne}

Umiejętność porozumienia się w sytuacjach życia codziennego, takich jak zakupy w sklepie spożywczym, wizyta w banku czy na poczcie, pytanie o drogę, umówienie się do lekarza ogólnego lub specjalisty, zmiana terminu konsultacji itd., można uznać za podstawę kompetencji komunikacyjnej. Role klienta, podróżnego, gościa czy pacjenta uwzględnione są w zestawie umiejętności wymaganych już na poziomie A2. Dialog z egzaminatorem dotyczący tych tematów stanowi też jedno z zadań w procesie certyfikacji na poziomie B1 (por. RMNiSW 2016).

Jeszcze do niedawna motywacją do nabycia kompetencji językowych pozwalających sprostać wymienionym sytuacjom były nie tylko wymogi egzaminacyjne, lecz także (a może przede wszystkim) konieczność poradzenia sobie w codziennych sytuacjach w środowisku polskojęzycznym i chęć porozumienia się z Polakami. Obecnie jednak coraz częściej załatwiamy różne sprawy drogą elektroniczna, za pośrednictwem stron i formularzy internetowych czy odpowiednich aplikacji. Potrzeba (a czasem możliwość) przeprowadzenia odpowiedniej rozmowy zdarza się coraz rzadziej. Problem ten zauważono już jakiś czas temu wraz z rosnąca popularnością robienia zakupów w hipermarketach i galeriach handlowych. Dialog z ekspedientem przestał być wymogiem w sytuacji, gdy wybrany przedmiot wystarczy zdjąć z półki i pokazać w kasie. Dla wielu kursantów żmudna nauka liczebników straciła także sens wraz z powszechnym wprowadzeniem możliwości zapłacenia kartą bankowa. Krążący wśród części lektorów i uczniów żart dotyczący zredukowania dialogu w sklepie spożywczym do replik „PIN, zielony, dziękuję, do widzenia" szybko przestał być wyłącznie humorystyczną opowiastka.

Obecnie z podobnym ograniczeniem spotykamy się w wielu sytuacjach życia codziennego. Przez Internet, wypełniając odpowiedni formularz, możemy zamówić taksówkę, umówić się na wizytę u lekarza specjalisty, doko- 
nać zakupów (także spożywczych), obsłużyć konto bankowe, opłacić rachunki, zamówić usługę kurierską etc. Różne aplikacje zainstalowane w telefonach lub innych sprzętach elektronicznych pozwalają nam uniknąc zadawania pytania o drogę, zakupu biletu komunikacji miejskiej lub dalekobieżnej w kiosku czy kasie na dworcu kolejowym. Zauważmy też, że ten elektroniczny sposób porozumiewania się, niewymagający osobistego kontaktu ani formułowania wypowiedzi ustnych, jest często promowany i preferowany przez osoby zarządzające firmami i instytucjami, pozwala bowiem uniknać kolejek, blokowania linii telefonicznych, kosztów zatrudniania dodatkowych pracowników obsługi, nieporozumień dotyczących pisowni nazw własnych itd. W sytuacji pandemii minimalizuje także ryzyko zarażenia się wirusem.

Wydaje się natomiast, że konsekwencje upowszechnienia się tej formy komunikacji w procesie nabywania języka i posługiwania się nim wciąż nie są wystarczająco często przedmiotem rozważań glottodydaktycznych. Choć analizuje się często i wprowadza na lekcji słownictwo związane z pojawieniem się nowoczesnych technologii, a sporo uwagi poświęca się nowym formom komunikacji, takim jak: czat, dyskusje w mediach społecznościowych etc., warto zauważyć, że wpływ tych zjawisk na sam proces nabywania i używania języka obcego jest znacznie szerszy. Na uwage zasługuja problemy takie, jak: 1) uwzględnienie wśród strategii językowych opisanych w ESOKJ przechodzenia od odmiany ustnej (wymagającej czynnej znajomości języka i uruchomienia sprawności mówienia) do pisanej (która, w wypadku stron i aplikacji internetowych, wymaga często jedynie znajomości biernej i wykorzystania sprawności pisania w bardzo ograniczonym stopniu); 2) coraz większy rozdźwięk między poziomami biegłości i standardami wymagań egzaminacyjnych a faktyczną „biegłością” i „efektywnością” uczących się w określonej sytuacji komunikacyjnej, tj. fakt, że - nawet nie dysponując odpowiednią wiedzą językową - są oni w stanie poradzić sobie w codziennym życiu; 3) różnice między słownictwem i strukturami gramatycznymi dotyc zącymi nowoczesnych technologii a leksyką i formami fleksyjnymi potrzebnymi do obsługi stron i aplikacji elektronicznych; 4) spadek motywacji studentów do opanowywania trudnych form gramatycznych, gdy są w stanie poradzić sobie z daną sytuacją komunikacyjną za pomocą ograniczonego kodu pisanego.

Poniżej odniosę się pokrótce do każdego z wymienionych zagadnień. Celem niniejszego artykułu jest więc wstępna refleksja nad tym, czy i w jakim stopniu opisywane tu procesy moga mieć wpływ na glottodydaktykę - 
w wymiarze teoretycznym, dotyczącym np. opisu kompetencji i strategii komunikacyjnych użytkowników języka, a przede wszystkim praktycznym, odnoszącym się do kształtu programów nauczania, treści i przebiegu lekcji oraz formy egzaminów certyfikatowych z języka polskiego jako obcego.

\section{Korzystanie z komunikacji elektronicznej jako jedna ze strategii komunikacyjnych}

Kompetencją komunikacyjną nazywa się zdolność użytkownika języka do zdobycia i przekazania informacji w mowie i w piśmie „w sposób poprawny i odpowiedni do danej sytuacji" (Komorowska 2005, 10). Autorzy ESOKJ zauważaja, że służy temu szereg zabiegów i działań, opisywanych jako strategie komunikacyjne. Co ciekawe, metoda polegająca na zastąpieniu komunikacji ustnej przez pisemną nie została (przynajmniej nie w sposób eksplicytny) opisana w podrozdziale ESOKJ poświęconym strategiom językowym (ESOKJ 2003, 61-75), choć te ostatnie zdefiniowano jako „środki wykorzystywane przez użytkownika języka w celu mobilizacji i kontroli własnych zasobów językowych oraz uaktywnienia własnych umiejętności i sposobów działania, by w najpełniejszy i najbardziej ekonomiczny sposób, zgodnie z założonym celem i danym kontekstem komunikacyjnym, skutecznie wykonać dane zadani e" (ESOKJ 2003, 61, wyróżnienie - A.W.). Przedstawiając strategie produktywne (dotyczące mówienia i pisania), autorzy cytowanego opracowania wymieniają działania takie, jak: dostosowywanie zadania (oznaczające m.in. jego realizację w skromniejszej formie, odpowiadającej możliwościom użytkownika, np. napisanie pocztówki zamiast listu - lub odwrotnie, utrudnienie zadania), dostosowywanie pržekazu (dopasowanie treści wypowiedzi do dostępnych środków językowych), kompensacja (parafrazowanie, użycie wyrażeń prostszych czy wręcz kalk z ojczystego języka etc.) czy autokorekta. Nie wspominają natomiast o świadomym wyborze, którego często dokonują obcokrajowcy, decydując się na zastąpienie komunikacji ustnej jakąś forma kontaktu elektronicznego. Wydaje się jednak, że ten zabieg stosowany jest we współczesnej rzeczywistości na tyle powszechnie, że warto byłoby uwzględnić go w opisie strategii komunikacyjnych i rozważyć jego praktyczne konsekwencje. 


\section{Poziom biegłości językowej wg ESOKJ, a poziom „biegłości" w codziennym życiu}

Korzystanie z różnych form komunikacji elektronicznej nie sprawia oczywiście, że rodzimi użytkownicy języka traca zdolność produkowania zrozumiałych, adekwatnych do kontekstu, wypowiedzi ustnych - ani też nie powoduje, że nigdy jej nie nabędą. W wypadku obcokrajowców zagadnienie to wydaje się jednak bardziej skomplikowane. Z jednej strony jest jasne, że chcąc osiagnąć poziom kompetencji komunikacyjnej zbliżony do rodzimego użytkownika - cudzoziemcy muszą opanować struktury gramatyczne, leksykę i sprawność pragmatyczną niezbędną w codziennych sytuacjach. Inaczej trudno oczywiście mówić o znajomości języka na danym poziomie biegłości. Tę właśnie znajomość słownictwa, form i struktur maja między innymi za zadanie sprawdzać egzaminy certyfikatowe.

Z drugiej strony, nawet wówczas, gdy obcokrajowcy muszą poradzić sobie w polskiej rzeczywistości, mieszkając w naszym kraju, coraz łatwiej jest im załatwiać codzienne sprawy bez czynnej znajomości języka mówionego, co świetnie ukazuje przywołany na początku tego artykułu autentyczny dialog. Można więc powiedzieć, że obecnie umiejętność funkcjonowania w danym kraju nie zawsze znajduje odzwierciedlenie w poziomie biegłości językowej określonym w standardach ESOKJ. Dzięki rozwiązaniom elektronicznym, które wymagają biernej znajomości pisanego rejestru języka, a nie czynnej znajomości odmiany ustnej, obcokrajowcy są w stanie poradzić sobie równie skutecznie jak rodzimi użytkownicy polszczyzny. Dzieje się tak często nawet wówczas, gdy cudzoziemiec nie zna odpowiednich form fleksyjnych i struktur składniowych. Zauważmy, że w formularzach elektronicznych i aplikacjach elementy na liście do wyboru najczęściej pojawiaja się w mianowniku albo innej - już podanej - formie gramatycznej. Oczywiście, rozdźwięk między znajomością regul języka, a umiejętnością komunikowania się to problem znany. Obcokrajowcy już wcześniej umieli radzić sobie w prostych sytuacjach codziennych, nawet nie produkując zdań całkowicie poprawnych. Obecnie jednak moga porozumiewać się drogą elektroniczną i używać odpowiednich aplikacji tak skutecznie, jak czynią to rodzimi użytkownicy języka polskiego.

Otwarte pozostaje pytanie, czy opisywane tu zjawiska moga i powinny znaleźć odzwierciedlenie w strukturze egzaminów certyfikatowych. Wprowadzanie rozwiązań testujących umiejętność radzenia sobie w elektronicz- 
nym świecie nie wydaje się ani łatwe technicznie (trudno orzec, jak wówczas miałby wyglądać egzamin, czy chodziłoby o część pisemną, czy o zastąpienie części egzaminu ustnego zadaniami polegającymi na załatwianiu spraw przez internet etc.), ani celowe - bo przecież, poza wypełnieniem odpowiedniego formularza elektronicznego, student musi być także w stanie porozumieć się bezpośrednio (porozmawiać z lekarzem, taksówkarzem, zrozumieć ogłoszenie na dworcu, zareagować na niespodziewany problem itd.). Rozwiązanie takie nie jest zreszta praktykowane w przypadku egzaminów certyfikatowych z innych języków. Warto byłoby natomiast rozważyć uzupełnienie podręczników i programów nauczania o odpowiednie treści leksykalne i gramatyczne oraz ćwiczenia praktyczne z wykorzystaniem internetu.

\section{Relacja język-technologia w praktyce glottodydaktycznej}

Jak trafnie zauważa Adam Pawłowski:

doświadczenie ostatnich stuleci pokazuje, że wpływ techniki na język uwidacznia się najwyraźniej w dwóch obszarach. Pierwszym jest podsystem semantyczno-leksykalny, który powinien oferować użytkownikom możliwość nazywania i opisywania nieznanych wcześniej artefaktów lub bytów abstrakcyjnych (...). Drugi obszar (...) wyznaczają wynalazki lub inne rozwiązania usprawniające procesy komunikacyjne (Pawłowski 2017, 112).

W pierwszym wypadku przedmiotem analizy językoznawczej mogą więc być m.in. zapożyczenia i neologizmy (internet, laptop itd.), metafory (surfować $w$ sieci), neosemantyzmy (siec) i formacje słowotwórcze (czat $\rightarrow$ czatowac) służące do nazywania elementów rzeczywistości związanych z wykorzystaniem najnowszych technologii (Pawłowski 2017, 112). Kwestie te są uwzględniane także w glottodydaktyce, zarówno w programach nauczania, jak i w podręcznikach jpjo. W Programach nauczania jezyka polskiego jako obcego dla poziomów A1-C2 wymieniono w katalogu tematycznym dla poziomu B1 zagadnienia takie, jak „,rozwój techniki - komputeryzacja” czy „media: prasa, radio, telewizja, Internet” (PNJPJO, 77), dla poziomu B2 - „zakupy z katalogu, z ofert telewizyjnych, sprzedaż sieciowa” oraz „telekomunikacja” (PNJPJO, 111-112), dla C1 - „aukcje (także internetowe) (PNJPJO, 147), 
a dla poziomu C2 - „nowe technologie a rynek pracy” (PNJPJO, 184). Lekcje poświęcone słownictwu związanemu z internetem i najnowszymi technologiami znajdziemy też w niektórych podręcznikach do nauczania jpjo (por. np. Stelmach, Stempek 2012, 40-41).

W odniesieniu do drugiego wymienianego przez Pawłowskiego obszaru rozważania językoznawcze dotyczą określonych sposobów komunikacji, takich jak: czat, forum internetowe, publiczna dyskusja w mediach społecznościowych etc., a analizy skupiają się najczęściej na ich nowej, skróconej formie, na słownictwie, którym posługują się ich użytkownicy, a także na wpływie komunikacji elektronicznej na życie społeczne (por. np. Grzenia 2012). Najnowsza publikacja Mirosława Wobalisa porusza także m.in. kwestię kompetencji cyfrowej w kształceniu polonistów (Wobalis 2017).

Z perspektywy dydaktyki jpjo rozważania te wydają się jednak niewystarczające. Zauważmy, że do używania aplikacji internetowych i wypełniania formularzy elektronicznych potrzebna jest także znajomość dość specyficznej leksyki i struktur gramatycznych, nieomawianych zwykle na lekcjach jpjo lub wprowadzanych na poziomie znacznie wyższym niż ten, który reprezentuje obcokrajowiec korzystający z internetu. Chodzi tu nie tyle o specjalną odmianę słownictwa, którą posługują się np. użytkownicy czatu, lecz o wyrażenia i zwroty niezbędne do załatwiania spraw w sieci. Już pobieżna obserwacja kilku wybranych stron internetowych i aplikacji pokazuje na przy$\mathrm{kład}^{1}$, że wykorzystuje się w nich powszechnie formy drugiej osoby liczby pojedynczej trybu rozkazującego czasowników dokonanych i niedokonanych (najczęściej pojawiające się to: kup, zamów, znajd乏́, (wy)szukaj, kontynuij, akceptuj, potwierd乏́, pozwól, nie pozwalaj, idź dalej, wróć, zarejestruj, umów, zaloguj sie, wpisz, rozwin, pokaż itd.). Zagadnienie trybu rozkazującego przypisane jest w RMNiSW do poziomu A2, co znajduje odzwierciedlenie w treści podręczników do nauczania jpjo. Rozkaźnika nie omawia się w pierwszej części popularnych podręczników takich, jak: Hurra! Po polsku (dalej Hurra), Polski, krok po kroku (KPK), Polski jest cool (PJC) czy Jezylk polski? Chce i moge! (JPCM). Pojawia się on dość późno w następujących opracowaniach przeznaczonych na poziom B1: Polski bez tajemnic, cz. 1 (PBT 2010, 115) czy Hurra, cz. 2 (Hurra 2 2010, 106). Jest to umotywowane logicznym układem zagadnień gramatycznych i stopniowaniem trudności. W obliczu zachodzących współcześnie zmian w sposobach komunikowania się warto jednak rozwa-

1 Wykorzystano treść stron internetowych: jakdojade.pl, pkp.pl, eletaxi.pl, telepizza.pl, pizzahut.pl, pocztex.pl, medicover.pl, szpitalmatopat.pl. 
żyć wprowadzenie wymienionych wyżej czasowników jak najwcześniej. Lista form możliwych do uwzględnienia już na poziomie A1 lub wczesnym A2 obejmowałaby prawdopodobnie nie więcej niż 20-25 najczęściej powtarzających się czasowników. Na tym etapie można by po prostu wprowadzić na lekcji określoną leksykę, niekoniecznie zapoznając uczniów z (dość złożonymi) regułami tworzenia form trybu rozkazującego.

Korzystanie ze stron internetowych i aplikacji wymaga też znajomości odpowiedniego słownictwa. Wśród najczęściej pojawiających się wyrażeń odnotowano dość uniwersalne, jak: login, hasło, płatność (karta), ostatnio squkane, przejdź do koszyka, wpisz kod widoczny na obrazku, zamówienie bez rejestracji, temat/treśc wiadomości, a także wyrażenia związane z danym typem aplikacji i usług, por.: strefa pasażera, wczésniejsže/późniejsz̧e połaczenia, stacja poczqtkowalkońcowa (pkp.pl); z. dostawa, na wynos (pizzahut.pl), aplikacja chce użý informacji o twoim polożeniu, punkt startowy, punkt docelowy, odjazd za... (jakdojade.pl); śledzenie przesytek, termin odbioru, miejsce doręczenia, prazybliżona masa (pocztex.pl); skad, dokad, docelowa lokalizacja (eletaxi.pl), umów wizyte, zobacz. dostepne wiayty (medicover.pl) etc.

Słownictwo tego typu, pozwalające załatwiać codzienne sprawy w sposób niewymagający użycia rozwiniętych wypowiedzi, nie jest na ogół uwzględniane w programach ani w podręcznikach do nauczania jpjo, zwłaszcza na niższych poziomach ${ }^{2}$, choć, jak zauważają sami autorzy ESOKJ, „we wspó1czesnym świecie - świecie nowoczesnych transakcji - używa się języka coraz oszczędniej, a właściwie tylko wtedy, gdy trzeba sobie poradzić z problemami zdarzającymi się w interakcjach, które zwykle są prowadzone bezosobowo i półautomatycznie" (ESOKJ 2003, 113). Najnowsze podręczniki wykorzystują często zdjęcia i skany tekstów autentycznych, takich jak: dowód osobisty, bilety komunikacji miejskiej i dalekobieżnej, bilety wstępu, oferty hoteli, rozmaite formularze etc. W opracowaniu JPCM (2018, 41-143) zamieszczono np. wyniki przeszukiwania połączeń kolejowych ze strony pkp.pl. Nie zmienia to faktu, że przedmiotem wyjaśnień i ćwiczeń leksykalnych jest tylko słownictwo podstawowe (pociag, peron, odjazd etc.), nie uwzględniono natomiast wyrażeń wymienionych w poprzednim akapicie, które pojawiają się w wyszukiwarce. Krótki przegląd powszechnie używanych podręczników na poziom A1/A2 pozwala stwierdzić, że jest to sytuacja typowa. Mimo że sygnalizuje się uczniom istnienie odpowiednich aplika-

2 Nie pojawia się też w materiałach przygotowujących do egzaminów certyfikatowych, w części poświęconej rozumieniu tekstów pisanych, w tym krótkich napisów i ogłoszeń, por. np. „Bądź na B1”. 
cji, brak ćwiczeń i wyjaśnień pozwalających sprawnie z nich korzystać. Wydaje się jednak, że temu problemowi można by dość łatwo zaradzić, wprowadzając na lekcji odpowiednie słownictwo już na wczesnym poziomie, co dałoby uczącym się możliwość używania programów i stron internetowych. Dzięki temu z pewnością podniosłoby się ich poczucie satysfakcji z większej samodzielności w codziennym funkcjonowaniu.

\section{Komunikacja internetowa a motywacja uczących się}

Jak wiadomo, złożoność systemu gramatycznego polszczyzny powoduje, iż - mimo coraz większego nacisku kładzionego na kształcenie umiejętności praktycznego porozumiewania się - obcokrajowcy zwykle dość późno stykają się na lekcji z podstawowymi sytuacjami komunikacyjnymi, takimi jak wizyta u lekarza (Hurra 1 2010, 122; KPK 1 2012, 166), kupowanie biletu kolejowego (Hurra 1 2010, 73; KPK 1 2012, 133), pytanie o droge (Hurra 1 2010, 102; JPCM 1 2018, 124), zamawianie taksówki (JPCM 2018, 126) czy dialog na poczcie (KPK1 2012, 102; temat nieuwzględniony w Hurra 1). Fakt, iż do porozumienia się w najprostszej choćby sytuacji potrzeba często wielu miesięcy pracy i opanowania dużej liczby form gramatycznych, często demotywuje uczących się. Dotyczy to zwłaszcza osób mieszkających w Polsce i/lub tych obcokrajowców, którzy nie uczyli się dotychczas języka o rozwiniętej fleksji.

Można zauważyć, że istnienie aplikacji internetowych pozwalających na wybieranie gotowych wyrazów $z$ listy, a przez to niewymagających znajomości i praktycznego używania wielu form gramatycznych, może być czynnikiem demotywującym dla części uczących się, którzy mogą teraz załatwić codzienne sprawy mimo nieznajomości gramatyki. W wypadku tych osób niezwykle ważna jest dalsza praca nad rozwijaniem sprawności językowych i wskazywanie na fakt, że w wielu sytuacjach komunikacja elektroniczna okazuje się niewystarczająca.

Z drugiej strony pojawienie się nowoczesnych form komunikacji można potraktować jako szansę dla tych uczniów, którym dotychczas niedostateczne opanowanie sprawności mówienia i gramatyki uniemożliwiało codzienne funkcjonowanie wśród Polaków. Uzupełnienie poszczególnych lekcji o leksykę i struktury gramatyczne niezbędne do używania stron i aplikacji internetowej pozwoliłoby wzmocnić motywację uczących się na tyle, aby byli w stanie poradzić sobie w sytuacjach, które dotąd ich przerastały. 


\section{Wnioski}

Nie ulega wątpliwości, że pojawienie się nowych form komunikacji elektronicznej wpływa znacząco na proces nauczania języków obcych, w tym także na zachowania i poziom motywacji uczniów. Powyższe rozważania zawierają jedynie wstępne obserwacje na przywołane tematy. Widoczna staje się potrzeba dalszej analizy. Zbadania wymagałoby m.in. to, jaki odsetek uczniów wie o istnieniu odpowiednich stron i aplikacji internetowych, ilu uczących się faktycznie zamierza z nich korzystać lub już to czyni ${ }^{3}$ etc., co wydaje się szczególnie ważne w obliczu wymuszonej przez pandemię komunikacji zdalnej. Konieczne byłyby też dokładniejsze analizy pojawiającej się na stronach internetowych leksyki i struktur, z uwzględnieniem bieżących potrzeb uczniów, takich jak np. korzystanie z elektronicznych platform, systemów i programów edukacyjnych typu USOS, Moodle czy Microsoft Teams. Wydaje się, że programy nauczania, a w konsekwencji treść podręczników już teraz można by uzupełnić o zagadnienia leksykalne i gramatyczne, pozwalające uczącym się na używanie stron i aplikacji elektronicznych w sytuacjach życia codziennego. Uzupełnienie takie nie musiałoby oznaczać naruszania logicznego i opartego na stopniowaniu trudności układu materiału dydaktycznego. Omawiając poszczególne sytuacje komunikacyjne, można by wprowadzić dodatkowe struktury i leksykę, co oznaczałoby na ogół nie więcej niż kilkanaście nowych wyrażeń oraz kilka form trybu rozkazującego. Warto by również, nie tylko w dobie zagrożenia epidemią, regularnie przeprowadzać lekcje z użyciem internetu, tak by uczący się mogli wypróbować istniejące już aplikacje. Uwzględnianie na zajęciach elektronicznych form komunikacji nie oznaczałoby oczywiście rezygnacji z „tradycyjnego” opanowywania odpowiednich wyrażeń i struktur, pozwoliłoby natomiast zwiększyć samodzielność życiową uczniów, przyczyniając się tym samym do wzrostu ich satysfakcji i kształtując przekonanie, że polszczyzna nie jest niemożliwym do opanowania i zastosowania w praktyce językiem. Przygotowałoby ich także do sytuacji takich jak obecna, w której korzystanie z komunikacji elektronicznej stało się koniecznością.

\footnotetext{
3 Osobny problem stanowi fakt, iż część aplikacji dostępna jest także w językach obcych, co demotywuje uczących się do korzystania z ich polskiej wersji.
} 


\section{Bibliografia}

Europejski system opisu ksqtatcenia jezykowego (ESOKJ), 2003, Warszawa.

Grzenia J., 2012, Co jezyk polski zawdziecza Internetowi? Na prayktadzie stownictwa, w: Markowski A., Pawelec R., red., Oblicza polszczyzny, Warszawa.

Janowska I., Lipińska E., Rabiej A., Seretny A., Turek P., red., 2011, Programy nauczania jezyka polskiego jako obcego. Poziomy A1-C2 (PNJPJO), Kraków.

Komorowska H., 2005, Metodyka nauczania jezykón obcych, Warszawa.

Pawłowski A., 2017, Technika, jezyk, cywilizacja, w: Kłosińska K., Zimny R., red., Przyszłłość polszçyzny - polszczyzna prayszłości, Warszawa.

Rozporzqdzenie ministra nauki i szkolnictwa wy ższego z 26 lutego 2016 r. w sprawie egzaminów z jezyka polskiego jako obcego (RMNiSW), 2016, http://certyfikatpolski.pl/wp-content/uploads/2018 /05/rozp_26_2_16.pdf [dostęp: 7.08.2019].

Wobalis M., 2017, Nowe media i technologie cyfrowe w ksz̧tałceniu polonistów, Poznań.

\section{Podręczniki}

Achtelik A., Hajduk-Gawron W., Madeja A., Świątek M., 2015, Bąź na B1, Kraków.

Burkat A., Jasińska A., 2010, Hurra!!! Po polsku 2 (Hurra 2), Kraków.

Gałat E., Sałęga-Bielowicz B., 2018, Jezyke polski? Chce i moge! cz. 1 (JPCM 1), Kraków.

Piotrowska-Rola E., Porębska M., 2013, Polski jest cool (PJC), Ćmiłów.

Skorupa E., Lipińska E., 2010, Polski bez tajemnic. Jezylk polski dla studentów niemieckojezycznych 1 (BPT), Kraków.

Stelmach A., Stempek I., 2012, Polski, krok po kroku 2 (KPK 2), Kraków.

Stempek I., Stelmach A., Dawidek S., Szymkiewicz A., 2015, Polski, krok po kroku 1 (KPK 2), Kraków.

Szymkiewicz A., Małolepsza M., 2010, Hurra!!! Po polsku 1 (Hurra 1), Kraków.

Aleksandra Walkiewicz - dr, Katedra Języków Romańskich, Uniwersytet Mikołaja Kopernika w Toruniu, Toruń, Polska.

Autorka monografii i artykułów poświęconych polsko-francuskiej gramatyce porównawczej oraz dydaktyce jpjo, ze szczególnym uwzględnieniem systemu czasownikowego i problematyki szyku. Opublikowała m.in.: Francuskie formy subjonctif i indicatif oraz ich polskie ekwiwalenty. Studium kontrastywne użyć w zdaniach złożonych (Toruń 2010), Revisiting the Correspondence Between the French Imparfait and the Polish Imperfective Aspect in the Distributed Grammar Framework, w: "Studies in Polish Linguistics" 7/2012 (z H. Włodarczyk), Teaching Word Order to Foreigners: From Theoretical Assumptions to Practical Solutions, w: „Kwartalnik Neofilologiczny” nr 4/2013 (z M. Gębką-Wolak). Kontakt: aleksandra.walkiewicz@umk.pl 